\title{
Does competition between soybeans and Wild Poinsettia with low- level resistance or susceptibility to glyphosate affect physiology and secondary metabolism?
}

\author{
A competição entre soja e leiteira com resistência de nível baixo \\ e suscetível ao glyphosate interfere na fisiologia e metabolismo \\ secundário?
}

\author{
André da Rosa Ulguim ${ }^{1 *}$; Dirceu Agostinetto²; Claudia de Oliveira ${ }^{3}$; Queli Ruchel ${ }^{3}$; \\ Jessica Dias Gomes da Silva ${ }^{4}$; Leandro Vargas ${ }^{5}$; Luis Antonio Avila ${ }^{2}$
}

\begin{abstract}
The Wild Poinsettia (Euphorbia heterophylla L.) has elevated potential to reduce the soybean yield and is a difficult to control plant due to herbicide resistance. The objectives of this study were to determine the changes in the photosynthetic physiological parameters, secondary metabolite levels, cellular damage, and antioxidant system activity in soybean plants and Wild Poinsettia biotypes with a low level of resistance or susceptibility to glyphosate in competition with soybeans. Two replacement series experiments were conducted in a greenhouse under competition between soybeans and the low-level resistant biotype (experiment I) or susceptible biotype (experiment II). The treatments consisted of different proportions of soybean plants and Wild Poinsettia [100:0 (pure stand of soybean), 50:50, and 0:100 (pure stand of Wild Poinsettia)] and different evaluation periods (the 2013/14 and 2014/15 growing seasons). The following parameters were analyzed: the chlorophyll, carotenoid (CRT), total phenol, hydrogen peroxide $\left(\mathrm{H}_{2} \mathrm{O}_{2}\right)$, and lipid peroxidation levels and the catalase (CAT), ascorbate peroxidase (APX), and superoxide dismutase (SOD) enzyme activity. Generally, competition between the soybeans and the Wild Poinsettia biotypes did not alter the photosynthetic parameters or the photosynthetic pigment levels of the crop. For the weed biotypes, competition with the soybeans negatively affected photosynthesis. Greater losses of chlorophylls and CRTs were observed for the susceptible biotype when in competition with soybeans, whereas the opposite trend was observed for the biotype with a low level of resistance. No cellular damage or alterations in antioxidant system enzyme activity was observed, which indicated a lack of oxidative stress.
\end{abstract}

Key words: Photosynthesis. Stomatal conductance. Chlorophyll. Carotenoids. Euphorbia heterophylla L.

\section{Resumo}

A leiteira (Euphorbia heterophylla L.) apresenta elevado potencial de redução da produtividade de soja, sendo uma planta de difícil controle devido aos casos de resistência a herbicidas. Os objetivos

\footnotetext{
${ }^{1}$ Eng $^{\circ}$ Agr ${ }^{\circ}$, Prof., Dr., Centro de Ciências Rurais, Universidade Federal de Santa Maria, UFSM, Santa Maria, RS, Brasil. E-mail: andre_ulguim@yahoo.com.br

${ }^{2}$ Eng $^{{ }^{-}}$Agr $^{\text {os }}$, Profs., Drs., Faculdade de Agronomia Eliseu Maciel, Universidade Federal de Pelotas, UFPel, Pelotas, RS, Brasil. E-mail: dirceu.agostinetto@pq.cnpq.br; laavilabr@gmail.com

${ }^{3}$ Eng $^{\circ}$ Agr ${ }^{\circ}$, M.e, Discente, Programa de Pós-Graduação em Fitossanidade, UFPel, Pelotas, RS, Brasil. E-mail: oliveirac.agro@ gmail.com; queli.ruchel@yahoo.com.br

${ }^{4}$ Discente de Graduação, Faculdade de Agronomia Eliseu Maciel, UFPel, Pelotas, RS, Brasil. E-mail: jessicadiasgomes@hotmail.com

${ }^{5}$ Eng $^{\circ}$ Agr ${ }^{\circ}$, Dr., Embrapa Trigo, Passo Fundo, RS, Brasil. E-mail: leandro.vargas@embrapa.br

* Author for correspondence
} 
desse trabalho foram determinar a alteração nos parâmetros fisiológicos fotossintéticos, o conteúdo de metabólitos secundários, os danos celulares e a atividade do sistema antioxidante em soja e em biótipo de leiteira resistente de nível baixo ou suscetível ao glyphosate, quando em competição com a soja. Foram realizados dois experimentos em casa de vegetação, em série de substituição, com a competição de soja com o biótipo resistente de nível baixo (experimento I) ou suscetível (experimento II). Os tratamentos constaram das proporções de plantas de soja e leiteira 100:0 (estande puro de soja), 50:50, e 0:100\% (estande puro de leiteira); e, das diferentes épocas de condução dos experimentos (safras 2013/14 e 2014/15). Foram analisados o teor de clorofila e carotenoides, fenóis totais, peróxido de hidrogênio, peroxidação lipídica e atividade das enzimas catalase, ascorbato peroxidase e superóxido dismutase. A competição de soja com os biótipos de leiteira, em geral, não alterou os parâmetros fotossintéticos e o teor de pigmentos fotossintéticos da cultura. Para os biótipos da planta daninha, a competição com a soja interferiu negativamente na fotossíntese, havendo maiores perdas de clorofilas e carotenoides para o biótipo suscetível quando em competição com a soja, sendo o contrário observado para o biótipo resistente de nível baixo. Não foram observados danos celulares ou alteração na atividade das enzimas do sistema antioxidante, indicando não haver estresse oxidativo.

Palavras-chave: Fotossíntese. Condutância estomática. Clorofila. Carotenoides. Euphorbia heterophylla $\mathrm{L}$.

\section{Introduction}

The Wild Poinsettia (Euphorbia heterophylla L.) has high potential to cause soybeanyield losses, which can be attributed to the photosynthetic efficiency of this species in relation to the crop (PROCOPIO et al., 2004). Studies in Brazil have shown resistance of the species to herbicides that inhibit acetolactate synthase (ALS) (VIDAL; MEROTTO JUNIOR., 1999) and protoporphyrinogen oxidase (PROTOX) (TREZZI et al., 2005) and that have a low level resistance to glyphosate (VARGAS et al., 2011). Herbicide resistance can interfere with the competitiveness of weeds (OLIVEIRA et al., 2014); therefore, this is an important issue for the maintenance of crop yields.

In response to competition, plants have developed the ability to synthesize various secondary compounds that are important for the interaction of the plants with the environment (CHEYNIER et al., 2013). Physiological factors are also related to the plant responses during competition (SILVA et al., 2014). Drought, nutrient depletion, and qualitative and quantitative radiation (AFIFI; SWANTON, 2012; BALLARÉ, 2009) are the main factors that influence the photosynthetic capacity of coexisting plants. For instance, the photosynthetic rate and the water use efficiency (WUE) are important factors that affect the competitiveness of the rice crop
(Oryza sativa L.) (CONCENÇO et al., 2011). Thus, the parameters related to photosynthesis can be indicative of the competitive damage to the plants (CONCENÇO et al., 2009; GALON et al., 2010).

The interception and use of light for photosynthesis are accomplished by the chlorophyll and carotenoid (CRT) pigments. Plants with the capacity to produce more of these pigments tend to have a competitive advantage (KASPARY et al., 2014). Chlorophyll $a$ (Chla) is the most abundant pigment in plants, whereas the other pigments, such as chlorophyll $b$ (Chlb) and the CRTs, operate in an accessory manner by capturing light and transmitting energy to the reaction centers (STREIT et al., 2005). The CRTs are also important photoprotectors of the chlorophylls by dissipating excess energy, aiding in the removal of reactive oxygen species (ROS) and suppressing damage to the photosynthetic apparatus (GILL; TUTEJA, 2010).

Under stress conditions, ROS production can overwhelm the removal mechanisms, thereby triggering oxidative stress (ESFANDIARI et al., 2010), generating damage to the cells and the DNA, and inducing lipid peroxidation and the loss of photosynthetic pigments (GILL; TUTEJA, 2010). In response to oxidative damage, plants develop alternatives for ROS removal (AFIFI; SWANTON, 2012), such as the enzymatic and non-enzymatic 
antioxidant defense systems (GILL; TUTEJA, 2010). The enzymatic antioxidant system operates through the sequential and simultaneous action of enzymes, such as superoxide dismutase (SOD), ascorbate peroxidase (APX), and catalase (CAT) (GILL; TUTEJA, 2010). In the non-enzymatic antioxidant system, phenolic compounds, CRTs, and proteins act along with other molecules (GILL; TUTEJA, 2010), and the levels of these compounds are indicative of oxidative stress. In a Conyza bonariensis (L.) Cronq. biotype resistant to glyphosate that was competing with soybeans, the reduction in the phenol levels, leakage of cellular electrolytes, and lipid peroxidation indicated that competition did not lead to oxidative stress, which differed from the response observed for the susceptible biotype (SILVA et al., 2014).

Knowledge of the metabolic responses resulting from the competition of Wild Poinsettia biotypes with either a low level of resistance or susceptibility to glyphosate with soybean plants is important for understanding the physiological responses of these species to competitive stress. Additionally, this knowledge will enable us to infer the potential loss of competitive ability due to resistance. Accordingly, the objectives of this study were to determine the alterations in the photosynthetic physiological parameters, secondary metabolite contents, cellular damage, and antioxidant system activity in soybean plants and Wild Poinsettia biotypes with either a low level of resistance or susceptibility to glyphosate in competition with soybeans.

\section{Materials and Methods}

Two replacement series experiments were performed in a greenhouse in combination with laboratory measurements between December 2013 and January 2014 and between November and December of 2014. The BMX Potência RR soybean cultivar and Wild Poinsettia biotypes susceptible to glyphosate (Panambi, 28²6’02”S, 5329'60'W; experiment I) and with a low level of resistance (resistance factor of 5.29) to glyphosate (Condor, $28^{\circ} 14^{\prime} 005^{\prime}$ 'S, 5336'582” W; experiment II) were used; these biotypes were selected based on a previous study (data not shown). The experimental design was completely randomized with three replications. The experimental units consisted of eight-liter pots with a $23 \mathrm{~cm}$ diameter that contained soil and the application of $210 \mathrm{~kg} \mathrm{ha}^{-1}$ of fertilizer in the 2-20-20 formulation.

The treatments were arranged in a factorial design in both experiments. Factor A consisted of the following proportions of soybean and Wild Poinsettia: 100:0 (pure stand of soybean), 50:50, and 0:100 (pure stand of Wild Poinsettia), which were equivalent to 20:0, 10:10, and 0:20 plants pot $^{-1}$, respectively. Factor $\mathrm{B}$ was composed of two different evaluation periods (the 2013/14 growing season and the 2014/15 growing season). Considering the statistical model used, the objective of the replications was to isolate the error within the growing season as a function of the plant proportions, whereas the growing season variable was used to validate the experiment as described by Piana et al. (2012).

Sowing was performed in polyethylene trays. The Wild Poinsettia and soybean plants were transplanted to the experimental units 15 and 11 days after sowing, respectively, when the first true leaves were fully expanded. During both growing seasons, the photosynthetic parameters were analyzed 30 and 40 days after transplantation (DAT) of the species using the last trifoliate leaf or fully expanded leaf when the soybean plants were in the $\mathrm{V}_{3}-\mathrm{V}_{4}$ and $\mathrm{V}_{5}-\mathrm{V}_{6}$ vegetative stages and the Wild Poinsettia plants had between 9-10 and 11-13 leaves, respectively. A infrared gas analyzer (IRGA) was used (LI-COR, LI-6400 model) with $\mathrm{CO}_{2}$ correction within the chamber to $400 \mu \mathrm{mol} \mathrm{mol}{ }^{-1}$ in addition to a leaf temperature of $22^{\circ} \mathrm{C}$ and an air flow of $500 \mu \mathrm{mol} \mathrm{s}{ }^{-1}$. The variables analyzed were the net photosynthesis (A), stomatal conductance (Gs), substomatal $\mathrm{CO}_{2}$ concentration (Ci), transpiration rate $(\mathrm{E})$, carboxylation efficiency (CE), and WUE; 
the latter two variables were analyzed using the A/ $\mathrm{Ci}$ and $\mathrm{A} / \mathrm{E}$ ratios, respectively.

Leaf samples were collected and stored at $-80^{\circ} \mathrm{C}$ at 45 DAT in both growing seasons (DE VOS et al., 2007). The chlorophyll and total CRT levels were determined using a $0.1 \mathrm{~g}$ sample and calculated using the formulas of Lichtenthaler (1987); the results were expressed in $\mathrm{mg} \mathrm{g}^{-1}$ of fresh weight (FW). The phenolic compound levels were determined via the method described by Singleton and Rossi (1965) in $1 \mathrm{~g}$ of plant material, and the results were expressed in $\mathrm{mg}$ of gallic acid equivalent (mg GAE) per gram of FW based on the GAE standard curve.

The cellular damages in the tissues were evaluated using the hydrogen peroxide $\left(\mathrm{H}_{2} \mathrm{O}_{2}\right)$ content as described by Sergiev et al. (1997). The cellular damage from thiobarbituric acid-reactive species (TBARS) was determined via the accumulation of malondialdehyde (MDA) as described by Heath and Packer (1968). The cellular damage was also evaluated via the relative permeability of the membranes determined through electrolyte leakage as described by Tarhanen et al. (1999).

To determine the activity of the antioxidant enzymes SOD, APX, and CAT, first the protein in the samples was quantified by Bradford's method (1976). The CAT and APX activity was determined following the method of Azevedo et al. (1998), whereas the SOD activity was determined with the methodology adapted from Giannopolitis and Ries (1977) using $0.2 \mathrm{~g}$ of plant material for the extraction.

The data obtained were analyzed for normality and homoscedasticity using the Shapiro-Wilk test and the Hartley test, respectively, which indicated the need to transform the data for the Gs, Ci, CE, CAT, and APX variables with the equation $\sqrt{ } \mathrm{X}+1$. The data were subsequently subjected to analysis of variance $(p \leq 0.05)$, with the effects of the factor proportion of the plants and repetition considered fixed and the effect of the factor growing season considered random, as described by Piana et al. (2012).
When statistical significance was found in the analysis of variance, the proportions were compared with the t-test $(\mathrm{p} \leq 0.05)$ for each competitor species and analyzed separately for the two experiments. The presence of correlations between the dependent variables of the study was analyzed using Pearson's correlation coefficient $(\mathrm{p} \leq 0.05)$.

\section{Results and Discussion}

In experiment I, the analysis of variance showed significance in the Wild Poinsettia for the variables A, Gs, Ci, E, and CE evaluated at 30 DAT and Gs evaluated at 40 DAT, the Chla and total chlorophyll (Chltot) levels, and the Chla/Chlb ratio. For the soybeans, significance was found for A, Gs, E, and $\mathrm{CE}$ evaluated at 30 DAT. In experiment II, significance was observed in the weed for the variables $\mathrm{CE}$ and WUE evaluated at $30 \mathrm{DAT}$ and for A evaluated at $40 \mathrm{DAT}$, for Chla, Chlb, Chltot, and Chla/Chlb, and for the CRT level. For the crop, significance was detected for CE at 30 DAT and Gs at 40 DAT, for Chla/Chlb, and for CRT. No significance was observed using the F-test for the other variables related to photosynthesis and secondary metabolism $(\mathrm{p} \leq 0.05)$. No significance was observed in any experiment for the total phenol levels, cellular oxidative damage, or SOD, CAT, and APX enzyme activity (data not shown).

In the first experiment, the analysis of the photosynthetic parameters showed higher values for A, Gs, E, and CE in the soybean plants at 30 DAT during monocropping (100:0) (Table 1). In the second experiment, only the $\mathrm{CE}$ was higher when the soybean plants were grown without competition compared to the plants grown together with the weed. The results suggest that competition was detrimental to the crop via affecting the gas exchange and the conversion of $\mathrm{CO}_{2}$ into photosynthetic assimilates at 30 DAT. Moreover, the results indicated greater damage to the crop from the competition with the susceptible biotype than from competition with the low-level resistance biotype during this evaluation 
period, with differences found in approximately $67 \%$ of the evaluated parameters (Table 1).

Generally, no difference was observed in the different proportions of soybean plants at 40 DAT regardless of the biotype of the competing Wild Poinsettia (Table 1). Considering the two evaluation periods and the two Wild Poinsettia biotypes, competition with the weed provided decrease on $20 \%$ and increase on $4 \%$ of the photosynthetic variables; however, we could not infer the greater or lesser competitiveness of the weed in relation to the crop.

In soybeans competing with Conyza bonariensis plants, A decreased with the increase in the coexistence period, which was related to stomatal closure due to the reduction in the quality of the light and the water availability (SILVA et al., 2014). The partial reduction of the stomatal opening limits the transpiration more than the influx of $\mathrm{CO}_{2}$ through the stomata (FIRMANO et al., 2009). Thus, the treatments with a higher E generally had a greater Gs for both species (Table 1), which indicated loss of water by transpiration due to stomatal opening.

For the Wild Poinsettia biotypes, the competition with soybeans was harmful in physiological terms (shown by the higher values of the variables analyzed during monocropping) regardless of the evaluation period, although only approximately one-third of the combinations were significant (Table 1). Thus, we can infer that interspecific competition is more damaging to the weed and negatively affects plant photosynthesis. Because the competitive ability among the Wild Poinsettia biotypes was not tested in this study, we could not determine which biotype was more competitive, and the results obtained did not enable differentiation of the biotypes in relation to their competitiveness with soybeans.
For most of the combinations tested, the increase in the Gs led to an increase in A regardless of the biotype, indicating that Gs may explain the results obtained for A (Table 1). A direct relationship is expected to exist between $A$ and $E$; thus, the increase in competition among plants may influence the availability of water, leading to the closure of the stomata and consequently the reduction in Gs and $\mathrm{E}$, which results in a lower A (GALON et al., 2013).

The variation in the Gs due to competition may affect the water supply. For instance, the increase in the Brachiaria brizantha (Hochst.) Stapf. population competing with sugarcane (Saccharum spp.) led to greater extraction of the water available in the soil, resulting in closure of the stomata (GALON et al., 2011). However, for soybeans competing with the Wild Poinsettia biotypes, water availability was not a determinant in the competition because the lack of water was not a limiting factor. Therefore, the competitive effects studied are more closely related to competition for light than for other environmental resources.

Radiation has a large effect on the stomatal opening of plants. In competing plants, radiation may be the main factor responsible for stomatal opening and closing (LORETO; BONGI, 1989). For instance, the low quality of light due to competition with weeds increased the number of closed stomata in the first leaves of corn (AFIFI; SWANTON, 2012). Thus, the photosynthetic responses for both species (but primarily the Wild Poinsettia biotypes) were due to the reduced light quality, which led to a general reduction in the Gs and lower A and CE when competing with soybeans, similar to the observations between rice genotypes (CONCENÇO et al., 2011). 
Table 1. Net photosynthesis (A) ( $\left.\mu \mathrm{mol} \mathrm{CO}_{2} \mathrm{~m}^{-2} \mathrm{~s}^{-1}\right)$, stomatal conductance (Gs) ( $\left.\mathrm{mol} \mathrm{H}_{2} \mathrm{O} \mathrm{m}^{-2} \mathrm{~s}^{-1}\right)$, substomatal $\mathrm{CO}_{2}$ concentration (Ci) $\left(\mu \mathrm{mol} \mathrm{CO} \mathrm{mol}^{-1}\right)$, transpiration rate $(\mathrm{E})\left(\mathrm{mmol} \mathrm{H}_{2} \mathrm{O} \mathrm{m}^{-2} \mathrm{~s}^{-1}\right)$, carboxylation efficiency $(\mathrm{CE})(\mu \mathrm{mol}$ $\mathrm{m}^{-2} \mathrm{~s}^{-1}$ ), and water use efficiency (WUE) $\left[\mu \mathrm{mol} \mathrm{CO} \mathrm{CO}_{2}\left(\mathrm{mmol} \mathrm{H}_{2} \mathrm{O}\right)^{-1}\right]$ of soybean plants (Glycine max (L.) Merr.) and Wild Poinsettia biotypes (Euphorbia heterophylla L.) with a low level of resistance or susceptibility under competition conditions evaluated 30 and 40 days after transplantation (DAT).

\begin{tabular}{|c|c|c|c|c|c|c|c|c|c|}
\hline \multirow{2}{*}{$\begin{array}{l}\text { Plant proportion } \\
\text { (soybean:Wild } \\
\text { Poinsettia) }\end{array}$} & $\mathrm{A}$ & \multicolumn{2}{|l|}{ Gs } & \multicolumn{2}{|l|}{$\mathrm{Ci}$} & $\mathrm{E}$ & $\mathrm{CE}$ & \multicolumn{2}{|l|}{ WUE } \\
\hline & \multicolumn{9}{|c|}{ Experiment I (soybean:susceptible Wild Poinsettia biotype) } \\
\hline \multicolumn{10}{|c|}{30 DAT } \\
\hline 100:0 & $9.15 \mathrm{a}^{1}$ & 0.19 & a & 276.33 & ns2 & $4.01 \mathrm{a}$ & 0.034 a & 2.45 & ns \\
\hline 50:50 & $5.99 \mathrm{~b}$ & 0.12 & $\mathrm{~b}$ & 271.75 & & $2.54 \mathrm{~b}$ & $0.022 \mathrm{~b}$ & 2.51 & \\
\hline $\mathrm{CV}(\%)$ & 17.19 & 3.30 & & 5.82 & & 12.34 & 0.54 & 8.49 & \\
\hline $0: 100$ & $20.75 \mathrm{a}$ & 0.73 & $\mathrm{a}$ & 299.33 & $\mathrm{a}$ & $7.42 \mathrm{a}$ & $0.069 \mathrm{a}$ & 2.89 & ns \\
\hline $50: 50$ & $12.31 \mathrm{~b}$ & 0.29 & $\mathrm{~b}$ & 264.17 & $\mathrm{~b}$ & $4.44 \mathrm{~b}$ & $0.045 \mathrm{~b}$ & 3.00 & \\
\hline CV (\%) & 12.65 & 7.79 & & 4.62 & & 13.44 & 0.59 & 5.38 & \\
\hline \multicolumn{10}{|c|}{40 DAT } \\
\hline 100:0 & 17.40 ns & 0.46 & ns & 233.42 & ns & $5.69 \mathrm{~ns}$ & 0.089 ns & 3.17 & ns \\
\hline 50:50 & 16.27 & 0.32 & & 221.92 & & 5.03 & 0.094 & 3.38 & \\
\hline CV (\%) & 7.16 & 7.25 & & 4.44 & & 7.59 & 0.97 & 4.21 & \\
\hline $0: 100$ & 23.08 ns & 0.94 & $\mathrm{a}$ & 228.93 & ns & $6.50 \mathrm{~ns}$ & 0.107 ns & 3.75 & ns \\
\hline $50: 50$ & 20.49 & 0.55 & $\mathrm{~b}$ & 227.98 & & 6.14 & 0.118 & 3.49 & \\
\hline $\mathrm{CV}(\%)$ & 7.15 & 8.08 & & 7.59 & & 3.90 & 1.84 & 5.08 & \\
\hline \multicolumn{10}{|c|}{ Experiment II (soybean:low level of resistance Wild Poinsettia biotype) } \\
\hline \multicolumn{10}{|c|}{30 DAT } \\
\hline 100:0 & 7.24 ns & 0.15 & ns & 256.00 & ns & 3.05 ns & 0.027 a & 2.60 & ns \\
\hline 50:50 & 6.10 & 0.16 & & 267.50 & & 3.10 & $0.021 \mathrm{~b}$ & 2.38 & \\
\hline CV $(\%)$ & 11.07 & 5.97 & & 4.69 & & 13.89 & 0.29 & 5.77 & \\
\hline $0: 100$ & 16.30 ns & 0.33 & ns & 249.67 & ns & $5.03 \mathrm{~ns}$ & 0.066 a & 3.52 & $\mathrm{a}$ \\
\hline $50: \mathbf{5 0}$ & 11.88 & 0.27 & & 254.00 & & 4.48 & $0.048 \quad \mathrm{~b}$ & 2.96 & $\mathrm{~b}$ \\
\hline CV (\%) & 20.62 & 8.09 & & 8.23 & & 20.63 & 0.90 & 6.86 & \\
\hline \multicolumn{10}{|c|}{40 DAT } \\
\hline 100:0 & 16.29 ns & 0.43 & $\mathrm{~b}$ & 248.08 & ns & 5.81 ns & 0.075 ns & 2.93 & $\begin{array}{l}\mathrm{ns} \\
\text { ns }\end{array}$ \\
\hline 50:50 & 18.01 & 0.74 & & 241.17 & & 6.34 & 0.081 & 3.06 & \\
\hline CV (\%) & 6.80 & 7.54 & & 5.71 & & 4.70 & 0.96 & 4.55 & \\
\hline $0: 100$ & 23.34 a & 0.83 & ns & 215.60 & ns & $6.79 \mathrm{~ns}$ & $0.177^{\text {ns }}$ & 3.66 & ns \\
\hline $50: \mathbf{5 0}$ & $21.13 \mathrm{~b}$ & 0.85 & & 213.64 & & 6.53 & 0.160 & 3.58 & \\
\hline CV (\%) & 5.46 & 6.23 & & 4.37 & & 4.17 & 2.17 & 3.08 & \\
\hline
\end{tabular}

${ }^{1}$ Means followed by the same letter in the column within species and evaluation periods do not differ significantly according to the t-test $(\mathrm{p} \leq 0.05) .{ }^{2}$ ns: not significant according to the F-test $(\mathrm{p} \leq 0.05)$.

For both biotypes studied, we observed that the CE was higher in the monocropped plants at 30 DAT and that the WUE was higher in the biotype with a low level of resistance (Table 1). This result was probably due to the closing of the stomata in the 50:50 proportion, which interfered with gas exchange and transpiration. However, the other variables involved in the calculation of these parameters were generally increased during monocropping. The significant differences were attributed to the higher A values of the monoculture, which were approximately 41 and $27 \%$ greater than the 50:50 proportion in the susceptible and lowlevel resistance biotypes, respectively. 
The WUE is directly related to the opening and closing of the stomata; water is lost through transpiration with varying intensities when the plants absorb $\mathrm{CO}_{2}$, depending on the potential gradient between the substomatal chamber in the leaf and the atmosphere (CONCENÇO et al., 2009). However, no differences were observed for this parameter in this study with the exception of the evaluation of the low-level resistance biotype at 30 DAT, indicating that this parameter was not relevant for the competitive effect of Wild Poinsettia plants with soybeans on photosynthesis in physiological terms (Table 1).

Notably, the growth, development, and phenological stage of the plants can influence photosynthesis and change the plant's response to variations in environmental factors (RIBEIRO et al., 2004). Thus, the evaluation period can interfere with the photosynthetic responses of the plants as shown herein, where differences between the evaluations at 30 and 40 DAT were observed. However, because the negative effects of competition were believed to a determinant in the responses obtained in this study, we decided to not perform a comparison between the evaluation periods and instead characterized them as distinct variables.

Regarding the photosynthetic pigment levels of the soybean plants, no difference was observed between the proportions of plants when the competitor was the susceptible biotype (Table 2). However, when the competitor was the biotype with low-level resistance to glyphosate, an increase in the Chla/Chlb and CRT was observed in the 50:50 proportion. Because a difference between the proportions for the soybean plants was observed in only two cases, we could infer that the competition with the Wild Poinsettia did not affect the chlorophyll and CRT levels in the crop.

Various agents (biotic and abiotic) can negatively regulate the Chla concentration in photosynthetic tissues by either increasing degradation (senescence) or inhibiting biosynthesis. The chlorophyll and CRT levels in the leaves are also indicative of the level of damage of the plant due to stress because chlorosis is often one of the first visible symptoms (CATUNDA et al., 2005). A reduction of approximately $6 \%$ in the foliar chlorophyll level in the soybean plants compared with the monoculture was found when the crop was grown together with the weed population (SABERALIA; MOHAMMADI, 2015). Competition also decreased the chlorophyll levels during the development of Cicer arietinum L. (AMARAL et al., 2015), which suggested that the magnitude of the damage was primarily dependent on the crop and the competing species. The CRTs are important plant pigments that absorb energy and transfer it to the chlorophyll and thus are considered accessory light-harvesting pigments. However, the CRTs also perform other functions, such as antioxidant functions that protect the photosynthetic apparatus of ROS and structural functions that play important roles in the functioning of photosystem I and the stability of the antenna complex (GILL; TUTEJA, 2010).

Different results were observed among the Wild Poinsettia biotypes for the competition with soybeans (Table 2). The susceptible biotype had higher Chla, Chltot, and Chla/Chlb levels when in monoculture; however, an increase in the Chla, Chlb, Chltot, and CRT levels was observed for the biotype with a low level of resistance to glyphosate when intercropped with soybeans compared to the monoculture. The differences in the photosynthetic pigment levels in the biotypes with resistance to glyphosate was previously reported; for example, higher Chla, Chlb, Chltot, and CRT levels were observed in the Conyza bonariensis biotype, and these levels were related to the greater competitive potential of this biotype compared to the susceptible biotype (KASPARY et al., 2014). Notably, the adaptability of the biotypes should not have affected the results of this study because biotypes originating from nearby locations were chosen for the analysis. 
Table 2. Levels of chlorophyll $a$ (Chla) ( $\left.\mathrm{mg} \mathrm{g}^{-1}\right)$, chlorophyll $b$ (Chlb) $\left(\mathrm{mg} \mathrm{g}^{-1}\right)$, total chlorophylls (Chltot) $\left(\mathrm{mg} \mathrm{g}^{-1}\right)$, Chla/Chlb ratio, and total carotenoids (CRTs) $\left(\mathrm{mg} \mathrm{g}^{-1}\right)$ in soybean plants (Glycine max (L.) Merr.) and Wild Poinsettia biotypes (Euphorbia heterophylla L.) with a low level of resistance or susceptibility under competition conditions 45 days after transplantation (DAT).

Plant proportion (soybean:Wild Poinsettia)
Chla
Chlb
Chltot
Chla/Chlb
CRTs

\begin{tabular}{|c|c|c|c|c|c|c|c|c|c|c|}
\hline \multicolumn{11}{|c|}{ Experiment I (soybean:susceptible Wild Poinsettia biotype) } \\
\hline 100:0 & 1.43 & ns & 0.72 & ns & 2.15 & ns & 1.92 & ns & 0.45 & ns \\
\hline 50:50 & 1.52 & & 0.74 & & 2.26 & & 1.99 & & 0.48 & \\
\hline CV $(\%)$ & 15.09 & & 16.39 & & 14.62 & & 10.89 & & 17.58 & \\
\hline $0: 100$ & 1.58 & a & 0.54 & ns & 2.12 & $\mathrm{a}$ & 2.95 & a & 0.43 & ns \\
\hline $50: 50$ & 1.40 & $\mathrm{~b}$ & 0.50 & & 1.89 & $\mathrm{~b}$ & 2.82 & $\mathrm{~b}$ & 0.41 & \\
\hline CV $(\%)$ & 9.10 & & 9.27 & & 8.93 & & 3.96 & & 8.51 & \\
\hline \multicolumn{11}{|c|}{ Experiment II (soybean: low level of resistance Wild Poinsettia biotype) } \\
\hline 100:0 & 1.21 & ns & 0.62 & ns & 1.83 & ns & 1.90 & $\mathrm{~b}$ & 0.41 & $\mathrm{~b}$ \\
\hline 50:50 & 1.29 & & 0.58 & & 1.86 & & 2.12 & a & 0.49 & $\mathrm{a}$ \\
\hline CV $(\%)$ & 18.97 & & 16.49 & & 17.72 & & 9.02 & & 13.35 & \\
\hline $0: 100$ & 1.26 & $\mathrm{~b}$ & 0.46 & $\mathrm{~b}$ & 1.71 & $\mathrm{~b}$ & 2.76 & $\mathrm{a}$ & 0.35 & b \\
\hline $50: 50$ & 1.54 & $\mathrm{a}$ & 0.63 & $\mathrm{a}$ & 2.17 & $\mathrm{a}$ & 2.48 & $\mathrm{~b}$ & 0.40 & $\mathrm{a}$ \\
\hline CV (\%) & 12.59 & & 11.79 & & 12.02 & & 6.05 & & 12.90 & \\
\hline
\end{tabular}

${ }^{1} \mathrm{~ns}$ : not significant according to the F-test $(\mathrm{p} \leq 0.05) .{ }^{2}$ Means followed by the same letter in the column within species do not differ significantly according to the t-test $(\mathrm{p} \leq 0.05)$.

Similar responses were observed in the Wild Poinsettia biotypes for Chla/Chlb even though different responses were obtained for the Chla and Chlb levels (Table 2). In the susceptible biotype, the increase in the Chla and Chlb levels was reflected in the increase in Chla/Chlb under the monoculture condition. However, for the biotype with a low level of resistance, Chla/Chlb was higher in the monoculture even with the higher chlorophyll levels detected in the 50:50 proportion. This response may be due to the magnitude of the loss of these pigments because Chla and Chlb were only reduced by 20 and $30 \%$ in the monoculture, respectively, and the $10 \%$ reduction in Chla/Chlb during intercropping was related to that difference. During the chlorophyll degradation process in the biotype with a low level of resistance, some of the Chlb was converted into Chla (ASHRAF; HARRIS, 2013), which increased the proportional content of Chla and affected the Chla/Chlb response.

The greatest accumulation of light energy occurs through the Chla (approximately $660 \mathrm{~nm}$ ), whereas Chlb absorbs light in two peaks (close to 500 and $650 \mathrm{~nm}$ ) (DI VITTORIO, 2009). Thus, Chla/ Chlb expresses the plant's ability to capture light under low luminosity conditions (NAKAZONO et al., 2001) with a typical value of 3:1 (STREIT et al., 2005). Plants with a lower Chla/Chlb have better performances even under shade conditions (NAKAZONO et al., 2001), as observed for the Wild Poinsettia intercropped with soybeans. Secondary metabolism can increase or decrease due to low luminosity, which mainly depends on the plant species (IBRAHIM; JAAFAR, 2012).

The Chlb, CRT, and Chla/Chlb levels in Camellia sinensis L. leaves decreased under full 
light compared with low light condition, whereas the Chla level was not affected (YANG et al., 2012). The lowest amount of radiation available for the Wild Poinsettia and soybeans was obtained in the intercropping condition because the canopy formed by more than one species was irregular and generated heterogeneity in the availability of light (POLLASTRINI et al., 2014). Thus, the results observed in this study related to the chlorophyll levels of the competing species were greatly influenced by the light availability and the competitive ability of the species and biotypes involved.

A diversion of substrates from primary metabolism occurs for the synthesis of secondary metabolites when faced with stresses; this diversion is responsible for the growth and development of plants (CHEYNIER et al., 2013). The competition between the production of chlorophyll and secondary metabolites under low radiation suggests a signal toward a shift from the investment in chlorophyll synthesis to the formation of other compounds (IBRAHIM; JAAFAR, 2012). This reduction in photosynthetic pigments may be due to the reallocation of carbon and nitrogen skeletons for the synthesis of secondary metabolic compounds (YANG et al., 2003). Thus, the analysis of the photosynthetic pigment levels in this study suggested that the effect from the competition for light in the different proportions affected the synthesis of photoassimilates and their allocation.

Compared to the weed monocropping, there was a tendency toward a reduction in the photosynthetic parameters in both biotypes during competition with soybeans (Table 1). However, based on the data obtained for the photosynthetic pigment levels, we can infer that the biotype with a low level of resistance had a lower capacity to reallocate the photoassimilates for the synthesis of other compounds or that the chlorophyll protection mechanism was more efficient compared with the susceptible biotype (Table 2). Other characteristics that could explain the losses of photosynthetic pigments were the phenol levels and antioxidant system activity.
Plants subjected to stress conditions have the characteristic of accumulating phenols in the tissues due to increased levels or the synthesis of novel compounds (CHEYNIER et al., 2013). In the plants of two rice cultivars intercropped with gulf cockspur grass, an increase was observed in the phenolic compound levels as the weed population during intercropping (HE et al., 2012). However, in this study, no effect on the phenol levels was found in the studied species. Moreover, the loss of chlorophyll and other components may result from the action of ROS (CHOE; MIN, 2006), which may affect the structure and the functionality of the photosynthetic apparatus, thereby inactivating the photosystem reaction centers (TRIPATHY et al., 2007). However, in the species tested in this work, no significance differences were observed for the evaluations involving oxidative stress; therefore, the observed responses cannot be attributed to these species.

Generally, the competition of soybeans with the Wild Poinsettia biotypes did not alter the photosynthetic parameters or the photosynthetic pigment levels of the soybean plants, with the exception of the photosynthetic evaluation at 30 DAT. However, for the weed biotypes, the competition with soybeans negatively affected photosynthesis (Table 1). Regarding the evaluation of the photosynthetic pigments, the responses indicated that the greatest losses of chlorophylls and CRTs for the susceptible biotype occurred when in competition with soybeans, whereas the opposite tend was observed for the biotype with a low level of resistance (Table 2). We could not infer the effect of competition from Wild Poinsettia plants on the soybean crop based on these results; however, interspecific competition seems to be more detrimental for the Wild Poinsettia based on the photosynthetic responses.

The Pearson correlation analysis showed positive and negative correlations for both experiments. For the experiment involving soybean competition with the susceptible biotype, the positive correlations 
of the phenol levels $\left(0.98^{*}\right)$ and Chla/Chlb $\left(0.98^{*}\right)$ with $\mathrm{H}_{2} \mathrm{O}_{2}$ were notable, as were the responses of A with GS $\left(0.99 *\right.$ and $0.95^{*}$ for evaluation at 30 and 40 DAT, respectively) or E (0.99* and $0.95^{*}$ for evaluation at 30 and 40 DAT, respectively) (data not shown). Negative correlations for the experiment with this biotype and soybeans were observed between $\mathrm{H}_{2} \mathrm{O}_{2}(-0.97 *)$, WUE at 30 DAT $(-0.99 *)$, $\mathrm{CE}$ at 40 DAT (-0.96*), and the Chlb level (data not shown).

Various studies have shown a correlation between lipid peroxidation and the chlorophyll level, indicating that the damages to the cell membranes trigger adverse effects on the photosynthetic apparatus (SUNOHARA et al., 2010; TRIPATHY et al., 2007; YIN et al., 2008). In this case, a negative correlation between Chla/Chlb and TBARS (-0.97*) was observed for the low-level resistance biotype competing with the soybean plants (data not shown). Conversely, the main positive correlations occurred between the phenol levels and Chla/Chlb $\left(0.95^{*}\right)$, A and Gs $(0.99 *$ for evaluation at $30 \mathrm{DAT}), \mathrm{A}$ and CE (1.00* and $0.97^{*}$ for evaluation at 30 and 40 DAT, respectively), and A and WUE (0.99* and 0.98* for evaluation at 30 and 40 DAT, respectively) (data not shown).

\section{Conclusions}

The competition between the susceptible Wild Poinsettia biotype or the biotype with low-level resistance to glyphosate and the soybean crop did not generally affect the photosynthesis of the soybean plants, although the interspecific competition was more damaging to the weed.

Generally, the chlorophyll and CRT levels were not altered in soybeans in competition with Wild Poinsettia plants regardless of the biotype. The levels of these pigments in the Wild Poinsettia biotype susceptible to glyphosate were generally reduced but were increased in the biotype with lowlevel resistance when in a population intercropped with soybean.
No oxidative stress, cellular damage, or activation of the antioxidant system was observed in either the Wild Poinsettia biotypes with low level resistance or susceptibility to glyphosate or in the soybean crop when in competition.

\section{Acknowledgments}

We would like to thank FAPERGS and CNPq for the financial support from Edital 22/2010 REPENSA.

\section{References}

AFIFI, M.; SWANTON, C. Early physiological mechanisms of weed competition. Weed Science, Athens, v. 60 , n. 4 , p. 542-551, 2012.

AMARAL, C. L.; PAVAN, G. B.; SOUZA, M. C.; MARTINS, J. V. F.; ALVES, P. L. C. A. Relações de interferência entre plantas daninhas e a cultura do grãode-bico. Bioscience Journal, Uberlandia, v. 31, n. 1, p. 37-47, 2015.

ASHRAF, M.; HARRIS, P. J. C. Photosynthesis under stressful environments: an overview. Photosynthetica, Praha, v. 51, n. 2, p. 163-190, 2013.

AZEVEDO, R. A.; ALAS, R. M.; SMITH, R. J.; LEA, P. J. Response of antioxidant enzymes to transfer from elevated carbon dioxide to air and ozone fumigation, in the leaves and roots of wild-type and a catalase-deficient mutant of barley. Physiologia Plantarum, Sweden, v. 104, n. 2, p 280-292, 1998.

BALLARÉ, C. L. Illuminated behaviour: phytochrome as a key regulator of light foraging and plant anti-herbivore defence. Plant, Cell and Environment, Logan, v. 32, n. 6, p. 713-725, 2009.

BRADFORD, M. A. Rapid and sensitive method for the quantitation of microgram quantities of protein utilizing the principle of dye binding. Analytical Biochemistry, New York, v. 72, n. 1, p. 248-254, 1976.

CATUNDA, M. G.; FREITAS, S. P.; OLIVEIRA, J. G.; SILVA, C. M. M. Efeitos de herbicidas na atividade fotossintética e no crescimento de abacaxi (Ananas comossus). Planta Daninha, Viçosa, v. 23, n. 1, p. 115121, 2005.

CHEYNIER, V.; COMTE, G.; DAVIES, K. M.; LATTANZIO, V.; MARTENS, S. Plant phenolics: recent advances on their biosynthesis, genetics, and 
ecophysiology. Plant Physiology and Biochemistry, Paris, v. 72, n. 1, p. 1-20, 2013.

CHOE, E.; MIN, D. B. Mechanisms and factors for edible oil oxidation. Comprehensive Reviews in Food Science and Food Safety, Chicago, v. 5, n. 4, p. 169-186, 2006.

CONCENÇO, G.; ASPIAZÚ, I.; GALON, L.; FERREIRA, E. A.; FREITAS, M. A. M.; FIALHO, C. M. T.; SCHWANKE, A. M. L.; FERREIRA, F. A.; SILVA, A. A. Photosynthetic characteristics of hybrid and conventional rice plants as a function of plant competition. Planta Daninha, Viçosa, v. 29, n. 4, p. 803809, 2011.

CONCENÇO, G.; SANT’ANNA, S. J.; SCHWANKE, A. M. L.; GALON, L.; FERREIRA, E. A.; ASPIAZÚ, I.; SILVA, A. F.; FERREIRA, F. A. Uso da água por plantas híbridas ou convencionais de arroz irrigado. Planta Daninha, Viçosa, v. 27, n. 3, p. 447-453, 2009.

DE VOS, R. C. H.; MOCO, S.; LOMMEN, A.; KEURENTJES, J. J.; BINO, R. J.; HALL, R. D. Untargeted large-scale plant metabolomics using liquid chromatography coupled to mass spectrometry. Nature Protocols, London, v. 2, n. 4, p. 778-791, 2007.

DI VITTORIO, A. V. Enhancing a leaf radiative transfer model to estimate concentrations and in-vivo specific absorption coefficients of total carotenoids and chlorophylls $\mathrm{a}$ and $\mathrm{b}$ from single-needle reflectance and transmittance. Remote Sensing of Environment, Berlin, v. 113, n. 9, p. 1948-1966, 2009.

ESFANDIARI, E.; SHOKRPOUR, M.; ALAVI-KIA, S. Effect of Mg deficiency on antioxidant enzymes activities and lipid peroxidation. Journal of Agricultural Science, Toronto, v. 2, n. 3, p. 131-136, 2010.

FIRMANO, R. S.; KUWAHARAI, F. A.; SOUZA, G. M. Relação entre adubação fosfatada e deficiência hídrica em soja. Ciência Rural, Santa Maria, v. 39, n. 7, p. $1967-$ 1973, 2009.

GALON, L.; CONCENÇO, G.; FERREIRA, E. A.; ASPIAZÚ, I.; SILVA, A. F.; FERREIRA, F. A.; SILVA, A. A.; TIRONI, S. P.; FREITAS, M. A. M.; SOARES, E. R. Eficiência de uso da água em genótipos de canade-açúcar submetidos a aplicação de herbicidas. Planta Daninha, Viçosa, v. 28, n. 4, p. 777-784, 2010.

GALON, L.; CONCENÇO, G.; TIRONI, S. P.; ROCHA, P. R. R.; SILVA, A. F.; ASPIAZÚ, I.; FERREIRA, E. A.; SILVA, A. A.; BORGES, E. T. Influence of Brachiaria brizantha in physiological characteristics related to photosynthesis and efficient use of water in sugarcane. Planta Daninha, Viçosa, v. 29, p. 1037-1043, 2011. Número Especial.
GALON, L.; FERREIRA, E. A.; CONCENÇO, G.; SILVA, A. A.; SILVA, D. V.; SILVA, A. F.; ASPIAZÚ, I.; VARGAS, L. Características fisiológicas de biótipos de Conyza bonariensis resistentes ao glyphosate cultivados sob competição. Planta Daninha, Viçosa, v. 31, n. 4, p. 859-866, 2013.

GIANNOPOLITIS, C. N.; RIES, S. K. Superoxide dismutase. Plant Physiology, Lancaster v. 59, n. 2, p. 309-314, 1977.

GILL, S. S.; TUTEJA, N. Reactive oxygen species and antioxidant machinery in abiotic stress tolerance in crop plants. Plant Physiology and Biochemistry, Paris, v. 48, n. 12, p. 909-930, 2010.

HE, H.; WANG, H.; FANG, C.; WU, H.; GUO, X.; LIU, C.; LIN, Z.; LIN, W. Barnyard grass stress up regulates the biosynthesis of phenolic compounds in allelopathic rice. Journal of Plant Physiology, Jena, v. 169, n. 17, p. 1747-1753, 2012.

HEATH, R. L.; PACKER, L. Photoperoxidation in isolated chloroplasts. I. kinetics and stoichiometry of fatty acid peroxidation. Archives of Biochemistry and Biophysics, Texas, v. 125, n. 1, p. 189-198, 1968.

IBRAHIM, M. H.; JAAFAR, H. Z. E. Primary, secondary metabolites, $\mathrm{H}_{2} \mathrm{O}_{2}$, malondialdehyde and photosynthetic responses of Orthosiphon stimaneus Benth. to different irradiance levels. Molecules, Basel, v. 17, n. 2, p. 11591176, 2012.

KASPARY, T. E.; LAMEGO, F. P.; CUTTI, L.; AGUIAR, A. C. M.; BELLÉ, C. Determination of photosynthetic pigments in fleabane biotypes susceptible and resistant to the herbicide glyphosate. Planta Daninha, Viçosa, v. 32, n. 2, p. 417-426, 2014.

LICHTENTHALER, H. K. Chlorophylls and carotenoids: pigment photosynthetic biomembranes. Methods of Enzymology, San Diego, v. 148, n. 1, p. 350-382, 1987.

LORETO, F.; BONGI, G. Combined low temperaturehigh light effects on gas exchange properties of jojoba leaves. Plant Physiology, Lancaster, v. 91, n. 4, p. 1580$1585,1989$.

NAKAZONO, E. M.; COSTA, M. C. da; FUTATSUGI, K.; M. PAULILO, T. S. Crescimento inicial de Euterpe edulis Mart. em diferentes regimes de luz. Brazilian Journal of Botany, São Paulo, v. 24, n. 2, p. 173-179, 2001.

OLIVEIRA, C.; AGOSTINETTO, D.; VARGAS, L.; ÁVILA, L. A.; TAROUCO, C. P. Does the resistance to glyphosate herbicide affect the competitive ability of ryegrass with soybean? Planta Daninha, Viçosa, v. 32, n. 1, p. 189-196, 2014. 
PIANA, C. F. B.; SILVA, J. G. C.; ANTUNES, I. F. Regionalização para o cultivo do feijão no Rio Grande do Sul com base na interação genótipo x ambiente. Revista Ceres, Viçosa, v. 59, n. 2, p. 213-224, 2012.

POLLASTRINI, M.; HOLLAND, V.; BRÜGGEMANN, W.; KORICHEVA, J.; JUSSILA, I.; SCHERERLORENZEN, M.; BERGER, S.; BUSSOTTI, F. Interactions and competition processes among tree species in young experimental mixed forests, assessed with chlorophyll fluorescence and leaf morphology. Plant Biology, Stuttgart, v. 16, n. 2, p. 323-331, 2014.

PROCOPIO, S. O.; SANTOS, J. B.; SILVA, A. A.; MARTINEZ, C. A.; WERLANG, R. C. Physiological characteristics of soybean and common bean crops and three weed species. Planta Daninha, Viçosa, v. 22, n. 2, p. 211-216, 2004.

RIBEIRO, R. V.; MACHADO, E. C.; OLIVEIRA, R. F. Growth- and leaf-temperature effects on photosynthesis of sweet orange seedlings infected with Xylella fastidiosa. Plant Pathology, Oxford, v. 53, n. 3, p. 334-340, 2004.

SABERALIA, S. F.; MOHAMMADI, K. Organic amendments application downweight the negative effects of weed competition on the soybean yield. Ecological Engineering, Amsterdam, v. 82, n. 1, p. 451-458, 2015.

SERGIEV, I.; ALEXIEVA, V.; KARANOV, E. Effect of spermine, atrazine and combination betwee $\mathrm{n}$ them on some endogenous protective systems and stress markers in plant. Comptes Rendus de l'Académie Bulgare des Sciences, Sofia, v. 51, n. 3, p. 121-124, 1997.

SILVA, D. R. O.; AGOSTINETTO, D.; VARGAS, L.; LANGARO, A. C.; DUARTE, T. V. Habilidade competitiva, alterações no metabolismo secundário e danos celulares de soja competindo com Conyza bonariensis resistente e suscetível a glyphosate. Planta Daninha, Viçosa, v. 32, n. 3, p. 579-589, 2014.

SINGLETON, V. L.; ROSSI, J. A. Colorimetry of total phenolics with phosphomolybdic-phosphotungstic acid reagents. American Journal of Enology and Viticulture, Davis, v. 16, n. 3, p. 144-158, 1965.

STREIT, N. M.; CANTERLE, L. P.; CANTO, M. W. do; HECKTHEUER, L. H. H. As clorofilas. Ciência Rural, Santa Maria, v. 35, n. 3, p. 748-755, 2005.

SUNOHARA, Y.; SHIRAI, S.; WONGKANTRAKORN, N.; MATSUMOTO, H. Sensitivity and physiological responses of Eleusine indica and Digitaria adscendens to herbicide quinclorac and 2,4-D. Environmental and Experimental Botany, Elmsford, v. 68, n. 2, p. 157-164, 2010.
TARHANEN, S.; METSARINNE, S.; HOLOPAINEN, T.; OKSANEN, J. Membrane permeability response of lichen Bryoria fuscescens to wet deposited heavy metals and acid rain. Environmental Pollution, Barking, v. 104, n. 1, p. 121-129, 1999.

TREZZI, M. M.; FELIPPI; C. L.; MATTEI, D.; SILVA, H. L.; NUNES, A. L.; DEBASTIANI, C.; VIDAL, R. A.; MARQUES, A. Multiple resistance of acetolactate synthase and protoporphyrinogen oxidase inhibitors in Euphorbia heterophylla biotypes. Journal of Environmental Science and Health Part B, New York, v. 40, n. 1, p. 101-109, 2005.

TRIPATHY, B. C.; MOHAPATRA, A.; GUPTA, I. Impairment of the photosynthetic apparatus by oxidase stress induced by photosensitization reaction of protoporphyrin IX. Biochimica et Biophysica Acta, Amsterdam, v. 1767, n. 6, p. 860-868, 2007.

VARGAS, L.; NOHATTO, M. A.; AGOSTINETTO, D.; BIANCHI, M. A.; GONÇALVES, E. M.; TOLEDO, R. E. Resposta de biótipos de Euphorbia heterophylla a doses de glyphosate. Planta Daninha, Viçosa, v. 29, p. 1121-1128, 2011. Número Especial.

VIDAL, R. A.; MEROTTO JUNIOR, A. Resistência de amendoim-bravo aos herbicidas inibidores da enzima acetolactato sintase. Planta Daninha, Viçosa, v. 17, n. 3, p. 267-373, 1999.

YANG, C. M.; YANG, M. M.; HUANG, M. Y.; HSU, J. M.; JANE, W. N. Herbivorous insect causes deficiency of pigment-protein complexes in an ovalpointed cecidomyiid gall of Machilus thunbergii leaves. Botanical Bulletin of Academia Sinica, Taipei, v. 44, n. 4, p. 314-321, 2003.

YANG, Z.; KOBAYASHI, E.; KATSUNO, T.; ASANUMA, T.; FUJIMORI, T.; ISHIKAWA, T.; TOMOMURA, M.; MOCHIZUKI, K.; WATASE, T.; NAKAMURA, Y; WATANABE, N. Characterisation of volatile and non-volatile metabolites in etiolated leaves of tea (Camellia sinensis) plants in the dark. Food Chemistry, Reading, v. 135, n. 4, p. 2268-2276, 2012.

YIN, X. L.; JIANG, L.; SONG, N. H.; YANG, H. Toxic reactivity of wheat (Triticum aestivum) plants to herbicide isoproturon. Journal of Agronomy and Food Chemistry, Washington, v. 56, n. 12, p. 4825-4831, 2008. 